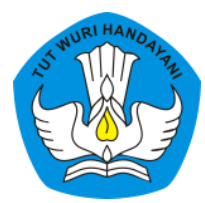

Page: 819-836

\title{
Peningkatan Kemampuan Membaca Permulaan Melalui Metode Drill
}

\author{
Rusmi Sumanty \\ Sekolah Dasar Negeri 3 Damar \\ Contributor Email: rusmisumanty70@gmail.com
}

Article Url: http://ojsdikdas.kemdikbud.go.id/index.php/didaktika/article/view/114

\begin{abstract}
The purpose of writing best practice is to describe the application of drill methods and Kacamata strategies (beautiful cards of various letters, syllables, and words) in improving the ability to read the1 grade students of elementary school 3 Damar, identify constraints of Drill. Problem solving strategies used are the drill method and the kacamata strategy. The implementation of the drill method is carried out three times a week by taking advantage of 20 minutes before effective learning hours begin, technical implementation is done by means of peer tutoring and games, while the strategy of glasses (beautiful cards of various letters, syllables, and words) here are in the form of substance or material in learning to read the beginning. Results achievied after filling for 3 stages until the eleventh week, there was significant progress, out of eleven students who were educated all studenst were able to rcognize letters and spell letters into syllabus, while students who have not been able to spell syllabus into words are only 1 students $(0,39 \%)$. Based on the data above, it turns out that the Drill method which was carried out in 3 stages for 3 months and combined with The Glasses strategy can improve the ability to read the beginning of students in grade 1 of Elementary School 3 Damar.
\end{abstract}

Keywords: Drill Methods; Kacamata Strategy; Problem Solving 


\begin{abstract}
Abstrak
Tujuan penulisan atikel ini adalah mendeskripsikan penerapan metode drill dan strategi "Kacamata" (Kartu Cantik Macam-macam Huruf, Suku Kata, dan Kata) dalam meningkatkan kemampuan membaca permulaan peserta didikkelas I SDNegeri(SDN) 3 Damar, mengidentifikasi kendala metode drill dan strategi "Kacamata"dalam meningkatkan kemampuan membaca permulaan peserta didik kelas I SDN 3 Damar, dan mengidentifikasi hasil atau dampak dari penerapan metode drill dan strategi "Kacamata"dalam meningkatkan kemampuan membaca permulaan peserta didik kelas 1 SDN 3 Damar.Strategi pemecahan masalah yang dipakai yaitu dengan metode drill dan strategi "Kacamata". Pelaksanaan metode drill dilakspeserta didikan tiga kali dalam seminggu dengan memanfaatkan waktu 20 menit sebelum jam belajar efektif dimulai, teknis pelaksanaannya dengan cara tutor sebaya dan permainan.Hasil yang dicapai setelah diterapkan selama tiga tahap sampai minggu ke-11, terdapat kemajuan yang signifikan, dari 11 peserta didik yang diujicoba semua peserta didik sudahdapat mengenal huruf dan mengeja huruf menjadi suku kata, sedangkan peserta didik yang belum bisa mengeja suku kata menjadi katahanyasatu peserta didik (0,39\%).Berdasarkan data di atas ternyata Metode drill yang dilakspeserta didikan dalam 3 tahap selama 3 bulan dan dipadukan dengan Strategi Kacamata dapat meningkatkan kemampuan membaca permulaan peserta didik di kelas I SDN 3 Damar.
\end{abstract}

Kata Kunci: Metode Driil, Strategi Kacamata; Penyelesaian Masalah

\title{
A. Pendahuluan
}

Sekolah Dasar Negeri (SDN) 3 Damar merupakan salah satu dari sembilan Sekolah Dasar di Kecamatan Damar Kabupaten Belitung Timur. SDN 3 Damar terletak di Jalan Sumatera Desa Mengkubang. SDN 3 Damar berdekatan dengan dua SD lainnya. yaitu SDN 1 Damar dan SDN 2 Damar. Letak yang berdekatan dengan dua SD lain di Kecamatan Damar, ketiga SDN berkompetisi untuk mendapatkan kepercayaan masyarakat yang akan memasukkan putra-putrinya untuk masuk sekolah dasar.

Pada tahun pelajaran 2018/2019 SDN 3 Damar menerima peserta didik baru sebanyak 28 peserta didik, dengan rincian 16 peserta didik laki-laki dan 12 peserta didik perempuan. Setelah diuji kemampuan membaca permulaan terhadap peserta didik baru, kemampuan membaca 
permulaan masih sangat rendah, permasalahan ini sama seperti ditemukan pada tahun-tahun sebelumnya. Adapun data yang didapat terhadap kemampuan membaca permulaan pada peserta didik kelas 1 SDN 3 Damar tahun pelajaran 2018/2019 dapat dilihat pada tabel 1.

Tabel 1. Kemampuan Membaca Permulaan Peserta didik Kelas 1

\begin{tabular}{lcc}
\hline Jenis Kelamin & Sudah Mampu Membaca & Belum Mampu Membaca \\
\hline Laki - Laki & 8 peserta didik & 8 peserta didik \\
Perempuan & 9 peserta didik & 3 peserta didik \\
Jumlah & 17 peserta didik & 11 Peserta didik \\
\hline \multicolumn{1}{c}{ Persentase } & 60,71 & 39,29 \\
\hline
\end{tabular}

Dari data tabel 1 menunjukkan bahwa hampir separuh peserta didik di kelas 1 SDN 3 Damar tahun pelajaran 2018/2019 belum mampu membaca, sementara membaca dan menulis permulaan merupakan prasyarat untuk mempelajari muatan pelajaran lain. Peserta didik yang berjumlah 11 peserta didik tentu akan mengalami kesulitan dalam belajar karena belum memiliki kemampuan membaca. Berdasarkan data tabel 1, dapat dijelaskan bahwa dari 11 peserta didik yang belum memiliki kemampuan membaca dapat dikategorikan antara lain: delapan peserta didik belum mengenal huruf dan belum dapat mengeja suku kata, dan tiga peserta didik sudah mengenal huruf dan sudah dapat mengeja huruf menjadi suku kata, tetapi belum bisa melafalkan (membaca rangkaian suku kata menjadi kata). Jika hal ini tidak disikapi oleh guru yang mengajar di kelas, maka selain peserta didik akan sulit mengikuti pembelajaran di kelas, juga akan berdampak pada hasil tes kemampuan dasar (3R) pada kelas tiga.

Berdasarkan fakta yang telah diuraikan, perlu dilakukan upaya memaksimalkan potensi peserta didik untuk meningkatkan kemampuan membaca permulaan, salah satunya dengan metode drill. Upaya yang dapat dilakukan dengan menerapkan metode drill yaitu dengan menggunakan strategi "Kacamata" (Kartu Cantik Macam-macam Huruf, Suku Kata dan Kata). Kegiatan ini memberikan waktu dan kesempatan kepada peserta didik untuk berlatih mengenal huruf, membaca (mengeja 
suku kata, dan kata) secara terus menerus melalui permainan dan tutor sebanya. Waktu yang digunakan guru dalam melakukan aktivitas membaca berulang-ulang (drill) selama lebih kurang 20 menit sebelum jam pelajaran dimulai. Diharapkan pada waktu pagi hari pikiran peserta didik-peserta didik masih jernih sehingga dapat memudahkan mereka menyerap pelajaran dibandingkan dengan siang hari usai pembelajaran di sekolah karena mereka sudah lelah dan jenuh belajar seharian di kelas. Selain itu, kegiatan ini tidak akan mengganggu jam efektif belajar di kelas. Program Kegiatan ini juga dilakukan oleh guru untuk mencapai salah satu dari enam misi sekolah yaitu: memberikan bekal kemampuan dasar baca, tulis, dan Hitung.

\section{Kemampuan Membaca Permulaan}

Pembelajaran membaca permulaan erat kaitannya dengan pembelajaran menulis permulaan. Sebelum mengajarkan menulis, guru terlebih dahulu mengenalkan bunyi suatu tulisan atau huruf yang terdapat pada kata-kata dalam kalimat. Pengenalan tulisan beserta bunyi dilakukan melalui pembelajaran membaca. Pembelajaran membaca di kelas satu dan dua merupakan pembelajaran membaca tahap awal. Kemampuan membaca yang diperoleh peserta didik di kelas satu dan dua menjadi dasar pembelajaran membaca di kelas berikutnya. Menurut Puji Santosa (2008 : 869) menyatakan bahwa pembelajaran membaca di SD terdiri dari dua bagian yakni: (a) membaca permulaan di kelas satu dan dua. Melalui membaca permulaan ini, diharapkan peserta didik mampu mengenali huruf, suku kata, kata, kalimat, dan mampu membaca dalam berbagai konteks. (b) membaca lanjut mulai dari kelas tiga dan seterusnya.

Kemampuan membaca permulaan merupakan kemampuan prasyarat untuk mempelajari dan mengerti ilmu pengetahuan lain. Menurut Kamus Besar Bahasa Indonesia (KBBI), kemampuan berarti kesanggupan atau kecakapan, sementara membaca berarti melihat serta memahami isi dari apa yang tertulis, atau mengeja dan melafalkan apa yang tertulis (KBBI, 
2008: 109). Membaca permulaan merupakan tahap awal dalam belajar membaca yang difokuskan kepada mengenal simbol-simbol atau tandatanda yang berkaitan dengan huruf-huruf, tahap ini menjadi fondasi agar peserta didik dapat melanjutkan membaca permulaan. Dari uraian yang telah dikemukakan dapat disimpulkan bahwa kemampuan membaca permulaan merupakan kecakapan untuk melihat, mengeja dan melafalkan lambang-lambang tulisan atau huruf-huruf yang kemudian diucapkan dengan menitikberatkan aspek ketepatan menyuarakan tulisan, lafal, kelancaran dan kejelasan suara.

Sajian utama peserta didik pada awal memasuki lingkungan sekolah yaitu program MMP (Membaca Menulis Permulaan). Dalam pelaksanaa di kelas dikenal bermacam-macam metode pembelajaran MMP. Metode tersebut antara lain sebagai berikut:

a. Metode eja

Metode ini memulai pembelajaran dengan mengenalkan hurufhuruf secara alfabetis. Huruf-huruf tersebut dihafalkan dan dilafalkan peserta didik sesuai dengan bunyinya menurut abjad. Contoh: Aa, Bb, Cc, Dd dan seterusnya, dilafalkan a, De, ce, Ed, dan seterusnya. Setelah melalui tahapan ini, peserta didik diajak berkenalan dengan suku kata dengan cara merangkai beberapa huruf yang sudah dikenal. Misalnya: $b$, a, ba (dibaca be, a, ba).

\section{b. Metode bunyi}

Metode ini merupakan bagian dari metode eja. Prinsip dasar dan proses pembelajaran tidak jauh berbeda dengan metode eja/abjad. Perbedaannya terletak pada pada sistem pelafalan abjad atau huruf, terutama huruf konsonan. Misal huruf b dilafalkan /eb/, huruf d dilafalkan /ed/, huruf c dilafalkan /ec/ dan sebagainya. Dengan demikian kata " ani" dieja menjadi:

en.a $\longrightarrow$ na $\quad$ en. $\mathrm{i} \longrightarrow$ ni dibaca: $\longrightarrow$ na -ni 


\section{c. Metode suku kata dan metode kata}

Metode ini diawali dengan pengenalan suku kata, seperti : ba, bi, bu, be, bo, ca, ci, cu, ce, co dan seterusnya. Suku kata tersebut kemudian dirangkai menjadi kata-kata bermakna. Misalnya: ba - bi, ca - ci, da - da.

d. Metode global

Metode ini melakukan pembelajaran MMP melalui proses diglobalisasi (proses penguraian kalimat menjadi satuan-satuan yang lebih kecil, seperti kata, suku kata, dan huruf). Misal: menguraikan salah satu kalimat menjadi kata, kata menjadi suku kata, dan suku kata menjadi huruf-huruf.

\section{e. Metode SAS}

Metode ini dimulai dengan pengenalan struktur kalimat, kemudian melalui proses analitik. Dari kalimat menjadi kata, dari kata menjadi suku kata, dari suku kata menjadi huruf, kemudian proses menyimpulkan, satuan-satuan bahasa yang telah terurai dikembalikan kembali menjadi satuan semula.

\section{Metode Drill}

a. Pengertian metode drill

Dalam proses pembelajaran, metode mempunyai peranan sangat penting untuk mencapai tujuan pembelajaran. Metode adalah suatu cara atau jalan yang ditempuh agar pembelajaran sesuai dan serasi untuk menyajikan pembelajaran agar tujuan dapat tercapai. Melalui pemilihan metode pembelajaran yang tepat tujuan pembelajaran akan tercapai. Menurut Nana Sudjana (1991) metode drill adalah suatu kegiatan untuk melakukan hal yang sama, secara sungguh-sungguh dengan tujuan untuk menyempurnakan suatu keterampilan secara permanen.

\section{b. Langkah-langkah metode drill}




\section{Rusmi Sumanty}

Metode drill dilaksanakan dalam pembelajaran dengan mengikuti langkah-langkah yang dilakukan guru dan peserta didik. Langkahlangkah yang dilakukan guru dalam menerapkan metode drill meliputi: (1) mempersiapkan pertanyaan-pertanyan beserta jawaban, (2) mengajukan pertanyaan secara lisan/tulis untuk melakukan sesuatu, (3) mendengarkan jawaban lisan/memeriksa jawaban tertulis, (4) dan mengajukan kembali berulang-ulang pertanyaan atau perintah yang diajukan. Sementara langkah-langkah yang dilakukan peserta didik meliputi: (1) mendengar baik-baik pertanyaan/perintah yang diajukan guru, (2) menjawab secara lisan, tertulis, melakukan gerakan seperti yang diperintahkan, (3) mengulang kembali jawaban/gerakan sebanyak permintaan guru dan (4) mendengarkan pertanyaan/perintah selanjutnya.

\section{c. Kelebihan dan kelemahan metode drill}

Metode drill yang diterapkan dalam pembelajaran di sekolah dasar memiliki kelebihan dan kelemahan. Kelebihan metode drill antara lain: (1) bahan pelajaran yang diberikan dalam suasana yang sungguh-sungguh akan lebih tertanam dalam ingatan peserta didik karena seluruh pikiran dikonsentrasikan pada materi yang dilatihkan, (2) peserta didik dapat mempergunakan daya fikirannya dengan bertambah baik, dan (3) adanya pengawasan, bimbingan dan koreksi langsung dari guru. Adapun kelemahan metode drill antara lain: (1) materi yang sama diulang-ulang akan menyebabkan kebosanan, (2) kebosanan yang terjadi pada peserta didik akan menyebabkan mogok belajar dan (3) latihan yang selalu diberikan dapat melemahkan kreativitas peserta didik.

\section{Strategi "Kacamata" (Kartu Cantik Huruf, Suku Kata, dan Kata)}

\section{a. Kartu cantik}

Dalam melaksanakan kegiatan pembelajaran di kelas guru akan memilih dan menggunakan strategi pembelajaran yang tepat. Strategi yang digunakan guru dalam pembelajaran di kelas, belum tentu tepat dan 
baik digunakan guru lain. Pemilihan metode, disesuaikan dengan situasi dan kondisi peserta didik. Pelaksanaan program kegiatan yang diterapkan guru dalam meningkatkan kemampuan membaca permulaan adalah pembelajaran tanpa buku. Salah satu alternatif strategi yang digunakan guru yaitu memperkenalkan huruf, suku kata, kata, dengan menggunakan kartu-kartu cantik, baik kartu huruf, kartu suku kata, maupun kartu kata.

Menurut KBBI (2008: 128) kartu adalah lembar empat persegi panjang untuk permainan beragam memiliki tanda, gambar, dan nomor di sisinya, sementara cantik artinya bagus sekali (antara bentuk, rupa dan lainnya tampak serasi). Jadi, kartu cantik di sini dapat diartikan media dua dimensi dengan ukuran segi empat berupa huruf, suku kata, kata yang tampak serasi antara warna huruf dan kartu.

\section{b. Kartu huruf, suku kata, dan kata}

Kartu huruf, suku kata, kata merupakan media yang termasuk pada jenis media grafis atau media dua dimensi, yaitu media yang memiliki ukuran panjang dan lebar. Menurut Arsyad (2011: 121) menjelaskan bahwa kartu huruf (suku kata, kata) adalah kartu kecil yang berisi gambar-gambar, teks, atau simbol yang mengingatkan atau menuntun peserta didik kepada sesuatu yang berhubungan dengan gambar itu, dapat digunakan untuk melatih peserta didik mengeja dan memperkaya perbendaharaan kosa kata. Kartu-kartu tersebut dapat dipindah- pindahkan sesuai keinginan pembuat suku kata, kata maupun kalimat. Penggunaan kartu huruf ini sangat menarik perhatian dan sangat mudah digunakan dalam pelajaran membaca permulaan. Kartu huruf ini biasanya dibuat bertujuan untuk memperbaiki dan meningkatkan kemampuan membaca permulaan peserta didik kelas satu dan dua. Media kartu bertujuan untuk mempermudah dalam mengkondisikan situasi belajar. Keterlibatan peserta didik secara aplikatif dan efisien. Guru bertindak sebagai fasilitator dalam kegiatan pembelajaran yang dilaksanakan peserta didik. 


\section{c. Manfaat kartu huruf}

Kartu huruf dapat dikategorikan ke dalam media visual, yaitu media yang dapat dilihat, dibaca dan diraba. Media ini mengandalkan indra penglihatan dan peraba. Ada beberapa manfaat kartu huruf antara lain: (1) memperjelas penyajian pesan agar tidak terlalu bersifat verbalistis, (2) mengatasi keterbatasan ruang, waktu, dan daya indra, (3) menimbulkan kegairahan belajar dan (4) memungkinkan peserta didik didik beajar sendiri menurut kemampuan dan minatnya.

Dari uraian yang telah dikemukakan, permasalahan yang menjadi fokus dalam penelitian ini yaitu: (1) bagaimana upaya yang dilakukan guru dalam meningkatkan kemampuan membaca permulaan peserta didik di kelas satu SDN 3 Damar? (2) apakah kendala yang dihadapi guru dalam penerapan metode drill dengan strategi "Kacamata"? bagaimana hasil atau dampak dari metode drill dengan strategi "Kacamata" dalam meningkatkan kemampuan membaca permulaan peserta didik kelas 1 SDN 3 Damar? Adapun tujuan dari penelitian ini yaitu: (1) mendeskripsikan penerapan metode drill dengan strategi "Kacamata" dalam meningkatkan membaca permulaan peserta didik kelas satu SDN 3 Damar, (2) mengidentifikasi kendala metode drill strategi kacamata dalam meningkatkan kemampuan membaca permulaan peserta didik kelas satu SDN 3 Damar dan (3) mengidentifikasi hasil atau dampak dari penerapan metode drill dengan strategi "Kacamata" dalam meningkatkan kemampuan membaca permulaan peserta didik kelas satu SDN 3 Damar.

\section{B. Metode}

Penelitian ini menggunakan pendekatan ex post facto. Sudjana dan Ibrahim (2007: 60) menjelaskan bahwa pendekatan ex post facto dimulai dengan mendiskripsikan situasi sekarang yang diasumsikan sebagai akibat dari faktor-faktor yang telah terjadi atau bereaksi sebelumnya. Dengan demikian, peneliti harus menoleh ke belakang (flash back) untuk 
menemukan faktor-faktor yang diasumsikan sebagai penyebab yang telah beroperasi pada masa lalu. Penelitian dilakukan di SD Negeri 3 Damar, Kabupaten Belitung Timur pada Agustus-November 2018. Subjek penelitian yaitu peserta didik di kelas satu semester satu tahun pelajaran 2018/2019 yang belum terampil membaca permulaan, belum dapat mengeja huruf menjadi suku kata, dan belum bisa mengeja suku kata menjadi kata.

Teknik pengumpulan data menggunakan observasi dan dokumentasi. Observasi merupakan kegiatan yang dilakukan untuk mengamati, merekam dan mendokumentasikan dari proses dan hasil yang dicapai. Perubahan yang terjadi baik yang ditimbulkan oleh tindakan yang terencana maupun akibat sampingannya. Adapun dokumentasi berupa data hasil pengamatan terhadap perilaku peserta didik dalam proses pembelajaran setiap pertemuan. Dokumentasi digunakan oleh peneliti sebagai data untuk menguji, menafsirkan dan menganalisis serta mengetahui perubahan atau peningkatan keaktifan maupun kemajuan, keberhasilan peserta didik dalam penerapan metode drill. Analisis penelitian dilakukan secara deskriptif kualitatif terhadap terhadap peningkatan kemampuan membaca permulaan melalui program drill dengan strategi "Kacamata".

\section{Hasil dan Pembahasan}

\section{Kondisi Awal}

Pada hari pertama masuk sekolah tahun pelajaran 2018/2019, SDN 3 Damar menjadwalkan kegiatan PLS (Pengenalan Lingkungan Sekolah) selama tiga hari. Tujuan PLS yaitu untuk mengenal lingkungan sekolah, di antaranya untuk mengenal potensi diri peserta didik baru, membantu peserta didik beradaptasi dengan lingkungan sekolah baru, menumbuhkan motivasi, semangat, dan cara belajar yang efektif sebagai peserta didik baru, mengembangkan interaksi positif antarpeserta didik dan warga sekolah. Dalam kegiatan PLS penulis mengenali potensi peserta didik, dengan melakukan tes kemampuan awal terhadap kemampuan baca tulis permulaan peserta didik. Dari hasil tes yang dilakukan data yang didapat 
dari kemampuan membaca dan menulis permulaan peserta didik kelas satu SDN 3 Damar tahun pelajaran 2018/2019 dapat dilihat pada gambar 1.

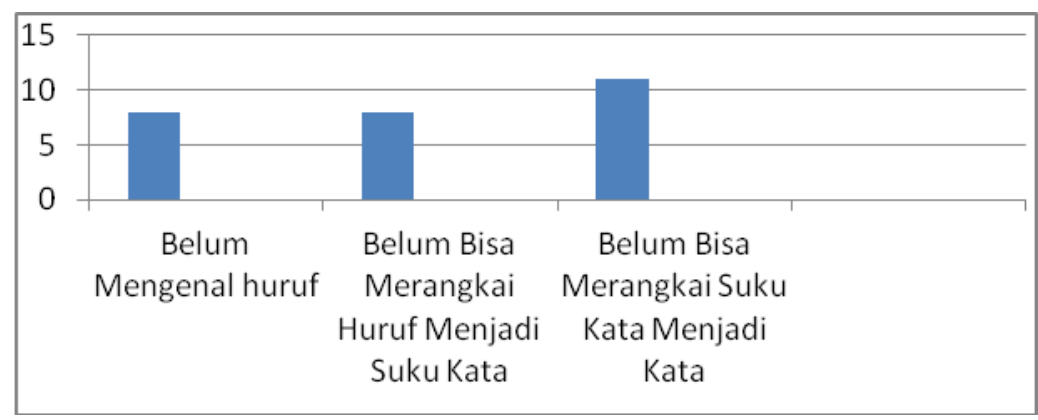

Gambar 1 Grafik Kemampuan Peserta Didik dalam Membaca Permulaan

Berdasarkan gambar 1, dapat dijelaskan bahwa sebelas peserta didik mengalami kendala dalam proses pembelajaran. Peserta didik akan mengalami kesulitan dalam menerima pelajaran di kelas karena belum memiliki kemampuan mengenal huruf dan membaca permulaan. Kemampuan membaca permulaan merupakan prasyarat untuk mempelajari muatan pelajaran lain. Oleh karena itu, peneliti berupaya mengambil tindakan untuk mengatasi masalah tersebut.

\section{Pemecahan Masalah}

Upaya/tindakan yang dilakukan terhadap peserta didik yang mengalami kesulitan dalam membaca permulaan seperti data yang telah diuraikan sebelumnya, peneliti berusaha untuk melakukan kegiatan dengan latihan berulang-ulang kepada peserta didik, yaitu dengan mengajak berlatih mengenal huruf, membaca (mengeja suku kata, dan kata). Waktu yang digunakan guru dalam melakukan latihan perulangan ini selama 20 menit, sebelum jam pelajaran di mulai. Memilih waktu sebelum jam pelajaran dimulai, dengan alasan bahwa di waktu pagi hari para peserta didik masih jernih pikirannya, sehingga dapat memudahkan mereka menyerap pelajaran, dibandingkan dengan siang hari setelah selesai pembelajaran di sekolah. Di waktu siang, peserta didik biasanya sudah lelah dan jenuh belajar seharian di kelas. Selain itu, waktu pagi 
tidak mengganggu jam efektif kegiatan belajar mengajar di kelas. Program kegiatan drill dilakukan tiga hari dalam seminggu yaitu pada selasa, rabu, dan kamis selama tiga bulan.

\section{Proses dan Hasil Pelaksanaan Metode Drill dan Strategi "Kacamata"}

1. Kegiatan pada tahap pertama

Pada tahap pertama guru mengharapkan agar peserta didik dapat mengenal huruf dan bukan menghafal abjad. Caranya: peserta didik dikenalkan abjad (huruf A sampai Z) melalui kartu huruf. Kartu huruf tersebut disusun oleh guru, peserta didik melafalkan huruf tersebut secara bergantian. Untuk menghindari kebosanan pada peserta didik, guru dan peserta didik melakukan permainan mengenal huruf (vokal dan konsonan). Setiap peserta didik diberi kartu huruf sebanyak lima buah. Salah satu peserta didik menyebutkan huruf vokal/konsonan, peserta didik menunjukkan kartu huruf vokal/konsonan yang dimaksud, jika benar peserta didik meletakkan kartu tersebut di bawah, jika salah peserta didik harus memegang kartu tersebut, demikian seterusnya. Peserta didik yang terlebih dahulu menghabiskan kartu huruf di tangan, dialah sebagai pemenang. Setelah melaksanakan kegiatan selama tiga minggu, penulis memantau kemajuan/perkembangan peserta didik dalam membaca permulaan.

Hasil yang didapat pada tahap pertama (tiga minggu pertama) yakni sebagai berikut: peserta didik yang mengalami kesulitan dalam membaca permulaan pada kondisi awal dengan rincian antara lain: (1) peserta didik yang belum mengenal huruf menurun, dari delapan menjadi empat peserta didik, (2) peserta didik yang belum dapat melafalkan huruf menjadi suku kata menurun, dari delapan menjadi enam peserta didik, dan (3) peserta didik yang belum dapat mengeja suku kata menjadi kata menurun, dari sebelas menjadi delapan peserta didik.

\section{Kegiatan pada tahap kedua}

Harapan guru yakni agar peserta didik dapat meningkatkan kemampuan mengeja gabungan dua huruf (konsonan dan vokal). Cara 
yang dapat dilakukan yaitu setiap peserta didik diberi kebebasan untuk memilih suku kata yang akan dieja menggunakan kartu suku kata yang disediakan. Suku kata yang akan dieja berupa gabungan huruf vokal dan konsonan. Misal: ma - ta, sa - tu. Apabila peserta didik sudah dapat mengeja suku kata dengan dua huruf, dilanjutkan kembali dengan mengeja dengan tiga huruf, berupa gabungan huruf konsonan-vokalkonsonan. Misalnya: sar, din, mas. Setelah kegiatan ini dilakukan selama empat minggu, peserta didik dievaluasi untuk mengetahui kemampuan peserta didik mengeja huruf menjadi suku kata. Cara yang dapat dilakukan guru yaitu dengan menunjukkan kartu suku kata kepada peserta didik, kemudian peserta didik mengeja gabungan huruf tersebut menjadi suku kata.

Setelah tahap dua dilakukan dengan melakukan pengulangan untuk berlatih membaca sudah terdapat kemajuan. Hasil yang diperoleh yaitu: (1) peserta didik yang belum mengenal huruf menurun, dari empat menjadi dua peserta didik, (2) peserta didik yang belum dapat merangkai huruf menjdi suku kata menurun, dari enam peserta didik menjadi empat peserta didik, (3) peserta didik yang belum dapat mengeja suku kata menjadi kata menurun, dari delapan menjadi enam peserta didik.

\section{Kegiatan pada tahap ketiga}

Harapan guru pada tahap ketiga yakni, agar peserta didik dapat mengeja atau membaca suku kata menjadi kata. Cara yang dilakukan pada tahap ini yaitu dengan melakukan permainan, mereka bebas memilih kartu suku kata yang akan dirangkai menjadi kata, kemudian kartu suku kata tersebut dapat dibongkar pasang sesuai dengan keinginan/kreativitas peserta didik. Kegiatan ini sangat menarik bagi peserta didik, karena melakukan kegiatan sambil bermain, peserta didik berkompetisi untuk mengeja (membaca suku kata menjadi kata yang disusun oleh temannya). Kemudian suku kata yang disusun tersebut ditanyakan kepada temannya yang lain. Pada tahap ini guru juga 
menyediakan kartu gambar dan kartu kata, permainan dilakuan dengan cara peserta didik diberi kartu kata, masing masing dua kartu. Kemudian guru menunjukkan kartu gambar, peserta didik membaca kartu kata yang dipegang, jika kartu kata yang dipegang bertuliskan nama benda yang dimaksud, peserta didik tersebut meletakkan kartu di bawah. Peserta didik yang berhasil menghabiskan kartu kata yang ada di tangan, dia sebagai pemenang permainan.

Kegiatan pada tahap ketiga dilakukan selama empat minggu. Usaha pengulangan terus dilakukan sampai minggu kesebelas. Setelah dievaluasi, terdapat kemajuan yang signifikan. Semua peserta didik sudah mengenal huruf, peserta didik yang belum dapat mengeja huruf menjadi suku kata, mengeja suku kata menjadi kata menurun menjadi satu peserta didik. Dari data perkembangan/kemajuan kemampuan membaca permulaan peserta didik di atas dapat disimpulkan bahwa metode drill dengan strategi "Kacamata" sangat efektif dan efisien. Kegiatan tersebut memberikan dampak yang cukup besar terhadap kemajuan kemampuan membaca permulaan peserta didik. Kemampuan membaca permulaan pada peserta didik sangat mempengaruhi prestasi belajar peserta didik karena kemampuan membaca permulaan pada peserta didik merupakan kunci/prasyarat untuk mempelajari muatan pelajaran lainnya.

Menurut Nur Farikatul Fitriyah (2010) dalam penelitiannya tentang penggunaan media kartu huruf dan kata melalui permainan untuk meningkatkan kemampuan membaca permulaan peserta didik kelas satu SDN Sudimoro 01 Kecamatan Bululawang menunjukkan bahwa ada peningkatan aktivitas dan hasil belajar peserta didik dengan menggunakan media kartu huruf. Hasil belajar peserta didik menunjukkan semula nilai rata-rata 70,91 persen meningkat menjadi 83,91 persen, sementara ketuntasan belajar semula 68,18 persen meningkat menjadi 95,5 persen. 
Dalam melakukan proses pengulangan (drill) tersebut ada beberapa faktor pendukung dan penghambat. Faktor pendukung terlaksanan metode drill antara lain: (1) media pembelajaran yang tersedia cukup memadai untuk melatih kemampuan membaca permulaan, (2) adanya kemauan,keinginan, semangat yang kuat dari peserta didik agar untuk bisa membaca, (3) adanya kepedulian dari guru kelas untuk membimbing peserta didik agar dapat membaca permulaan, di luar jam pelajaran, (4) adanya dukungan dari pihak/warga sekolah yang lain, yaitu kepala sekolah, guru-guru. Sementara yang menjadi faktor penghambat antara lain: (1) Penerapan metode drill yang dilakukan di kelas, menjadikan peserta didik kurang berkonsentrasi ketika melihat teman-teman lain yang sudah mengenal, mengeja dan membaca permulaan. Peserta didik yang sudah mampu membaca permulaan datang ke kelas, mereka tidak bergabung dengan peserta didik yang sedang berlatih. Hambatan ini dapat diatasi dengan cara, peserta didik yang sudah mengenal huruf dan dapat membaca suku kata dan kata, ketika datang ke kelas diminta untuk membaca buku paket secara mandiri. Guru sudah menyediakan buku paket di atas meja masing masing peserta didik. Dengan cara ini, guru secara tidak langsung telah menerapkan program literasi yang dicanangkan pemerintah. (2) Minimnya motivasi dari orang tua untuk bekerja bersama dalam menyatukan persepsi memberi bimbingan yang ekstra kepada peserta didik untuk melatih keterampilan membaca permulaan di rumah. Kendala dan hambatan ini diatasi dengan membuatkan buku kemajuan belajar peserta didik, terutama perkembangan kemampuan membaca permulaan untuk diketahui dari orang tua.

\section{Penutup}

Berdasarkan hasil penelitian dan pembahasan yang telah diuraikan dapat disimpulkan bahwa kemampuan membaca permulaan peserta didik kelas satu di SDN 3 Damar dapat meningkat melalui penerapan metode drill dengan strategi "Kacamata". Metode drill dilakukan dengan 
permainan dan tutor sebaya. Dalam meningkatkan keterampilan membaca permulaan menggunakan metode drill dengan strategi "Kacamata" terdapat sejumlah kendala. Namun demikian, kendala tersebut dapat diatasi, di antaranya: (1) peserta didik yang kurang berkonsentrasi ketika melihat teman-teman lain yang masuk kelas dan tidak bergabung dengan mereka, oleh guru diberikan tugas lain yaitu membaca buku yang telah disiapkan di atas meja. Hal ini sejalan dengan program literasi yang dicanangkan pemerintah. (2) minimnya motivasi dari orang tua untuk bekerja bersama dalam menyatukan persepsi memberi bimbingan yang ekstra kepada peserta didik untuk melatih keterampilan membaca permulaan di rumah. Kendala dan hambatan kedua diatasi dengan membuatkan buku kemajuan belajar peserta didik, terutama perkembangan kemampuan membaca setiap seminggu sekali untuk diketahui orang tua peserta didik. Berdasarkan langkah-langkah pelaksanaan metode drill dengan strategi "Kacamata" mulai pada tahap pertama sampai dengan tahap ketiga (selama 11 minggu), kemampuan membaca permulaan peserta didik kelas I SDN 3 Damar mengalami peningkatan yang signifikan yakni semua peserta didik sudah dapat mengenal huruf, sudah dapat merangkai (mengeja) huruf menjadi suku kata, sementara peserta didik yang belum dapat mengeja suku kata menjadi kata menurun menjadi satu peserta didik.

\section{Ucapan Terima Kasih}

Artikel ini dapat terselesaikan dengan baik karena bantuan dari berbagai pihak. Penulis ingin menyampaikan ucapan terima kasih dan penghargaan kepada pihak-pihak yang telah membantu penulisan artikel ini. Kepada kepala sekolah SDN 3 Damar yang telah memberikan kesempatan untuk melaksanakan penelitian dan pada redaktur Jurnal Didaktika yang telah memberikan saran dan masukan untuk perbaikan artikel. 


\section{Daftar Referensi}

Arsyad Azhar. (201). Media Pembelajaran. Jakarta: PT Raja Grafindo Persada

Casey, E., Kudeva, R., \& Rousson, A. (2018). Institutionalization of Religion in Schools to Intercultural Education. Jurnal Ilmiah Peuradeun, 6(1), 85-102. doi:10.26811/peuradeun.v6i1.215

Nana Sudjana. (1991). Dasar-Dasar Proses Belajar Mengajar. Bandung: Sinar Baru

Nur Farikatul Fitriyah. (2010). Penggunaan Media Kartu Huruf dan Kata melalui Permainan untuk Meningkatkan Kemampuan Membaca Permulaan Peserta didikKelas I SDN Sudimoro 01 Kecamatan Bululawang, Malang

Pamela, C., Villalobosl, L., \& Peralta, N. (2017). Difference Cultural Structure and Behavior Students in Learning Process. Jurnal Ilmiah Peuradeun, 5(1), 15-24. doi:10.26811/ peuradeun.v5i1.115

Puji Santosa. (2008). Materi dan Pembelajaran Bahasa Indonesia SD. Jakarta: Universitas Terbuka

TIM Penyusun Kamus Pusat Bahasa. (2008). Kamus Besar Bahasa Indonesia. Jakarta: Pusat Bahasa 
Vol. 4, No. 3, November 2020 